\title{
Education in War Affected Areas (Internally Displaced Persons communities) in Eastern Sudan
}

\author{
Dr. Randa Gindeel \\ School of Rural Extension, Education and Development \\ Ahfad University for Women \\ Arda Street, Omdurman, Sudan \\ E-mail: rgindeel@yahoo.com \\ James S. Etim, Ph.D. \\ Professor of Education, Department of Education \\ College of Arts, Science, Business and Education \\ Winston Salem State University, Winston Salem, NC 27110, USA \\ E-mail: etimj@wssu.edu
}

Received: Nov. 2, 2014 Accepted: Nov. 13, 2014 Published: November 13, 2014

doi:10.5296/jse.v4i4.6540 URL: http://dx.doi.org/10.5296/jse.v4i4.6540

\begin{abstract}
This exploratory study investigated the status of education in war torn communities of Eastern Sudan. A questionnaire was sent out to all the principals of the schools in four communities in war torn area of Eastern Sudan. There were also two visits to each of the schools. The study focused on these questions- (a) What are the levels, quality and the type of education provided to 5-16 year olds in the war affected towns/ areas of Eastern Sudan? (b) What are the gender make-up of teachers and principals and the educational qualification of teachers? (c) What are the numbers of subjects taught by grade level and the availability of textbooks for the subjects taught? (d) Are the textbooks written at the level of the students? (e) What are most threatening things to the education of the learner? (f) What are the numbers of school days for the school year and how much work are teachers able to cover during a school year with little or no conflicts compared with a school year with conflicts and natural disasters? Data was collected mainly by interviews of principals in the schools of the study area. An analysis of data from seven principals for all the schools in the area showed four of
\end{abstract}


the schools were built by NGO's, while three were built by the Government; that more than 57 percent of teachers had a bachelor's degree with a teaching certificate, that the average teaching experience for male teachers was 15 plus years and for female teachers, it was a little more than 6 years. In the areas of English Language, Mathematics and Science, it was found that textbooks were not available for about 50 percent of the students and that these textbooks were not at the level of the student. There were several threats to the continued education of the learner, the three most important being lack of feeding during the school day for students, lack of family support and early marriages for the girls. Recommendations in the study included campaigns to encourage students to stay in school, and the possibility of some law that will discourage parents from allowing early marriages (for ages less than 16) for the girls.

Keywords: Basic education, Curriculum, Gender, Teacher qualification, Textbooks, War torn areas 


\section{Introduction}

Sudan is one of the largest countries in Africa. According to the CIA World Fact book, it has a population of 35.4 million people, 61 percent of the population is under the age of 24 years and 33 percent live in urban centers (with a majority in Khartoum). The school life expectancy (primary to tertiary) is only four years (CIA World Fact Book, 2014).

Sudan has been affected by a cycle of major conflicts and devastations in the last fifty years (Department for International Development 2012 p.2). These conflicts and war and frequent droughts have resulted in migrations of people and the displacement of their daily lives. Since the 1980s and after the 2011 secession of South Sudan, Sudan has experienced extreme population displacement due to a combination of human-made and natural disasters. According to the Norwegian Agency for Development Cooperation (2011) the "Sudanese population has been seriously affected by the long-lasting civil war with a following humanitarian crisis ... a large number of internally displaced persons and refugees, with the consequent lack of economic and social development" (p.5).

An estimated 8.5 million people were displaced, mainly vulnerable women, youth and children, from western Sudan in the 1980s as a result of Saharan drought, over 3 million people displaced from southern, western and eastern Sudan in the 1980s-90s as a result of civil war and armed conflicts, and 2 million people displaced from Darfur since 2003. According to the International Crisis Group (2012) as cited in NORAD/ADRA Working Paper (2014), the fighting which shifted to marginalized areas such as South Kordofan, Blue Nile and Darfur led to the displacement of over 400,000 people, with over 300,000 seeking refuge in the outskirt of Khartoum. Other causes of displacement include natural hazards such as flooding and the worsening economic situation. (NORAD/ADRA Working Paper 2014)

\section{The Community for the Study}

Four communities were involved in the study. Two are described below since there are similarities with all the four communities- made up mostly of displaced persons from the conflict. One of the communities in the study is Fatou. It lies to the south of Rural Kassala Locality about 10 kilometres (twenty minutes' drive by car) from Kassala city. The community is composed of about 10 thousand members approximately and a little more than a thousand household. The population was displaced from the eastern bank of the Gash River, mainly from Diman, Badgair, Hawara Mountain, Hafara, Um Safari, Silkayay and Shambob and from the western bank of the Gish River, they were displaced from Al Laffa village. The Rural Kassala locality chose this place for them. Displacement took place on the $17^{\text {th }}$ of June 1998. Ethnic groups who live in the community are: Beni Amir (60\%), Hawsa (15\%), Hadedawa (10\%) and Falata (5\%). Most of the houses are constructed using mud and local material although some houses are built in a different way using bricks.

The second community was DablaweetSinkatKinab which lies at about $29 \mathrm{~km}$ from Kassala city and 10 minutes west of Shalaloub community. Houses are constructed from mud and local material (see figure 1). The base of the house is constructed from mud while the roof is 
from straws arranged in a special way to prevent rains from entering into the house. Locally, this type of hut is known as durdur.

Education is crucial to both personal and national development. According to UNICEF (nd)

Educating children gives the next generation the tools to fight poverty and prevent disease.. Educated girls are more likely to marry later and have fewer children, who in turn will be more likely to survive and to be better nourished and educated. Educated women are more productive at home and better paid in the workplace, and more able to participate in social, economic and political decision-making.

UNESCO (2012), indicated the importance of education in general and girls and women education in particular when the Organization declared:

The possibility of social mobility out of poverty must become a reality for larger proportions of national populations, particularly for girls and women.

Failure to ensure girls' access to secondary schooling increases the chances of transmitting poverty and illiteracy from generation to generation. A quality education, including in the areas of science and technology, can help ensure that girls and women can access decent jobs and make a real contribution to sustainable development in their communities (p.38).

In the same vein, USAID (2008) pointed out that "educating girls produces many additional socio-economic gains that benefit entire societies. These benefits include increased economic productivity, higher family incomes, delayed marriages, reduced fertility rates. (page. 1).

\section{Global Context for the Importance of Education}

In 1994, the United Nations declared 1995-2004 the UN Decade for Human Rights Education. In 1990 in Jomtien, Thailand (and reaffirmed again in 2000 in Dakar, Senegal) national governments, UNESCO and the World Bank committed themselves to bring education to every citizen in every society (UNESCO, World Declaration on Education for All). This Education for All project has as its aim six broad goals:

- $\quad$ Expand and improve comprehensive early childhood care and education, especially for the most vulnerable and disadvantaged children.

- $\quad$ Ensure that by 2015 all children, particularly girls, those in difficult circumstances and those belonging to ethnic minorities, have access to and complete, free and compulsory primary education of good quality.

- $\quad$ Ensure that the learning needs of all young people and adults are met through equitable access to appropriate learning and life-skills programs.

- Achieve a 50 per cent improvement in levels of adult literacy by 2015, especially for women, and equitable access to basic and continuing education for all adults. 
- $\quad$ Eliminate gender disparities in primary and secondary education by 2005 , and achieve gender equality in education by 2015, with a focus on ensuring girls' full and equal access to and achievement in basic education of good quality.

- Improve all aspects of the quality of education and ensure excellence of all so that recognized and measurable learning outcomes are achieved by all, especially in literacy, numeracy and essential life skills. (Education for All, 2007)

Apart from these broad goals, the Millennium Development Goal 3 sets out a target of eliminating gender disparity in primary and secondary education preferably by 2005 and at all levels by 2015 .

Data from UNICEF (nd) below in Table 1 provides information on education in Sudan in 2010 for primary and secondary school net attendance and survival rates.

Table 1. Primary and Secondary Net Attendance and Survival Rates, 2010.

\begin{tabular}{|l|l|l|l|}
\hline \multirow{2}{*}{} & \multicolumn{2}{|l|}{ Primary } & Secondary \\
\cline { 2 - 4 } & Attendance (in \%) & Survival (in \%) & Attendance (in \%) \\
\hline Total & 75 & 82 & 32 \\
\hline Male & 78 & 84 & 33 \\
\hline Female & 72 & 81 & 30 \\
\hline Urban & 89 & 89 & - \\
\hline Rural & 69 & 78 & - \\
\hline
\end{tabular}

Source: UNICEF (nd) UNICEF Data Monitoring the Situation of Women and Children. Retrieved October 10, 2014.http://data.unicef.org/education/overview

Notwithstanding this data in Table 1, the Department for International Development (2012p. 5) declared that, "Data availability and quality is extremely low in some areas of our work across Sudan."

\section{Purpose of Study}

In this study we intend to address the issue of data availability for war devastated Eastern Sudan. Specifically, the research aims to answer the following questions:

a. What are the levels, quality and type of education provided to 5-16 year olds in war torn affected towns/ areas in Eastern Sudan?

b. What are the gender make-up of teachers and principals and the educational qualification of teachers?

c. What are the numbers of subjects taught by grade level and the availability of textbooks for the subjects taught?

d. Are the textbooks written at the level of the students? 
e. What are the most threatening things for the education of the students?

f. What are the numbers of school days for the school year and how much work are teachers able to cover during a school year with little or no conflicts versus a school year with a lot of conflicts and natural disasters?

Specifically, the study will use the following data points to answer questions (a) to (f) above

- The number of schools both in terms of basic vs high secondary school.

- Type of school: boys' school - girls' school - mixed school.

- The total number of students and gender distribution and the number of teachers and gender distribution per school.

- Class size for each grade level.

- The distribution of boys and girls for each school.

- The average age for each grade level for both boys and girls.

- The curriculum- for each grade level, how many subjects are taught at each grade level and compare it with the curriculum from the ministry of education.

- What percentage from the curriculum do teachers manage to cover and the total number of school days for a school year with very few conflicts and natural disasters and the number of school days for a year with a lot of conflicts and natural disasters.

\section{Data Collection}

A questionnaire containing 25 items was developed for the study. It was given to two scholars in education for review to ensure their validity. For consistency, the questionnaire was then used as the schedule to interview the seven principals for all the schools in the study area. The interviews were conducted in August 2014.

\section{Data Analysis}

Data was collated and analyzed using frequency counts and percentages.

Question 1: What are the types, level, and quality of education provided to 5-16 years in war affected towns/ areas in Sudan?

Table 2 below showed school type for the seven schools visited in Rural Kassala Locality

Table 2. School Type for the study area

\begin{tabular}{|l|l|l|}
\hline Variable & Number & Percentage \\
\hline All boys & 3 & 42.85 \\
\hline All girls & 3 & 42.85 \\
\hline Coeducational & 1 & 14.30 \\
\hline
\end{tabular}




\section{Macrothink Institute ${ }^{T M}$}

For the study area, there were seven schools, three all boys, three all girls and one coeducational school. In terms of levels, all the schools were basic schools- primary schools. There were no upper secondary schools in the area.

A further analysis of type showed that of the seven schools, four schools were owned by NGO's and three by the Government. Table 3 below shows school ownership.

Table 3. School ownership

\begin{tabular}{|l|l|l|}
\hline Variable & Number & Percentage \\
\hline NGO's & 4 & 57.15 \\
\hline Government & 3 & 42.85 \\
\hline
\end{tabular}

Table 4 below shows the grade level for the seven schools in the study area together with the average age for the boys and girls in the schools.

Table 4. Grade level for the seven schools with the average age for each level

\begin{tabular}{|l|l|l|}
\hline \multirow{2}{*}{$\begin{array}{l}\text { Class level } \\
\text { (Grade) }\end{array}$} & Average age & Girls \\
\cline { 2 - 3 } & Boys & 7.67 \\
\hline 1 & 7.63 & 8.5 \\
\hline 2 & 8.17 & 9.34 \\
\hline 3 & 9.17 & 10.84 \\
\hline 4 & 10.34 & 11.75 \\
\hline 5 & 11.5 & 12.5 \\
\hline 6 & 13.25 & 13.5 \\
\hline 7 & 14.25 & 14.5 \\
\hline 8 & 15.25 & \\
\hline
\end{tabular}

The average age for grade 1 was 7 plus years. For each of the levels beginning in grade 6, girls were a little bit younger than boys.

Question 2: What is the gender make-up of teachers and principals, the educational qualification of teachers and the experience of teachers?

Table 5 below shows the gender make up of teachers for the seven schools.

Table 5. Gender Make up for Teachers

\begin{tabular}{|l|l|l|}
\hline \multirow{2}{*}{ Gender } & \multicolumn{2}{|l|}{ Teachers } \\
\cline { 2 - 3 } & Number & $\%$ \\
\hline Male & 16 & 38.10 \\
\hline Female & 26 & 61.90 \\
\hline
\end{tabular}


Table 5 above shows there were more female teachers than male teachers in the seven schools.

Table 6 below shows the gender make up for principals in the seven schools in the study

Table 6. Gender Make up for Principals

\begin{tabular}{|l|l|l|}
\hline \multirow{2}{*}{ Gender } & \multicolumn{2}{|l|}{ Principals } \\
\cline { 2 - 3 } & Number & $\%$ \\
\hline Male & 3 & $42-85$ \\
\hline Female & 4 & 57.15 \\
\hline
\end{tabular}

Table 6 above shows that there were more female principals for the seven schools.

In Table 7 below, data on teacher qualification are presented.

Table 7. Teacher qualification

\begin{tabular}{|l|l|l|}
\hline Variable & Teacher qualification & Percentage \\
\hline High secondary certificate & 11 & 26.18 \\
\hline B.A. of Education & 24 & 57.15 \\
\hline B.A. of Islamic Studies & 3 & 5.15 \\
\hline B.Sc. Accounting & 3 & 5.15 \\
\hline B.A. of Art & 1 & 2.37 \\
\hline Total & 42 & 100 \\
\hline
\end{tabular}

Table 7 above shows that 57.15 percent of teachers had a teaching qualification and more than 12 percent of teachers had a degree. Data above in Table 7 also shows that more than a quarter of the teachers had just secondary school certificate.

Table 8 below shows that on the average, male teachers had more than 15 years teaching experience and female teachers had six years of teaching experience.

Table 8. Teaching Experience by Gender

\begin{tabular}{|l|l|}
\hline Gender & Years of Teaching Experience \\
\hline Male & 15.25 \\
\hline Female & 6.89 \\
\hline
\end{tabular}

Question 3: What are the numbers of subjects taught by grade level and the availability of textbooks for the subjects taught?

Table 9 below shows the number of subjects taught at each grade level. Data shows that four subjects were taught in grades 1 and 2 and eight subjects were taught in grade 8 . The number of subjects taught matched the number of subjects to be taught as recommended by the Ministry of Education for each grade level. 


\section{1) Macrothink}

Table 9. Number of subjects taught at each grade level.

\begin{tabular}{|l|l|l|}
\hline $\begin{array}{l}\text { Class level } \\
\text { (Grade) }\end{array}$ & No. of subjects taught at each grade & $\begin{array}{l}\text { No. of subjects (curriculum) } \\
\text { from the Ministry of Education }\end{array}$ \\
\hline 1 & 4 & 4 \\
\hline 2 & 4 & 4 \\
\hline 3 & 5 & 5 \\
\hline 4 & 6 & 6 \\
\hline 5 & 6 & 6 \\
\hline 6 & 7 & 7 \\
\hline 7 & 8 & 8 \\
\hline 8 & 8 & 8 \\
\hline
\end{tabular}

Table 10 below presents data on the availability of textbooks for the subjects taught.

Table 10. Availability of Textbooks for subjects taught

\begin{tabular}{|l|l|l|l|l|}
\hline Class & Average & \multicolumn{3}{|l|}{ \% of textbooks in the classroom per subject } \\
\cline { 4 - 5 } $\begin{array}{l}\text { level } \\
\text { (Grade) }\end{array}$ & $\begin{array}{l}\text { No. } \\
\text { students }\end{array}$ & Mathematics & Science & English Language \\
\hline 1 & 46.25 & 64.29 & - & - \\
\hline 2 & 31.17 & 48.34 & - & - \\
\hline 3 & 26 & 38.00 & - & - \\
\hline 4 & 23 & 41.00 & 50.00 & - \\
\hline 5 & 20.40 & 45.00 & 50.00 & 46.67 \\
\hline 6 & 16.25 & 33.34 & 50.00 & 13.34 \\
\hline 7 & 18.34 & 22.50 & 40.00 & 10.00 \\
\hline 8 & 12 & 32.50 & 50.00 & 7.50 \\
\hline
\end{tabular}

Table 10 above showed that for most of the grades, there were more students than the textbooks available for instruction. For example, in Grade 5, only 50 percent of students had access to science textbooks and less than 50 percent had access in the areas of Mathematics and English Language. The situation is far worse in Grades 7 and 8. Only 10 percent or less in both grades had access to English Language textbook and less than 35 percent in both grades had access to Mathematics textbooks.

Question 4: Are the textbooks written at the level of the students?

Table 11 below presents data from the principals on the level of textbook for the student. 
Table 11. The textbooks are written at the level of the student.

\begin{tabular}{|l|l|l|}
\hline Variable & Number & Percentage \\
\hline Strongly agree & 2 & 28.58 \\
\hline Agree & 1 & 14.28 \\
\hline Disagree & 3 & 42.86 \\
\hline Strongly disagree & 1 & 14.28 \\
\hline
\end{tabular}

Data above in Table 11 showed that for the school principals more than 57 percent disagreed or strongly disagreed that the textbooks were written at the level of the student.

Question 5: What are the most threatening things for the education of the students?

Table 12 below shows the threats to the education of male students

Table 12. Threats to the education of male students

\begin{tabular}{|l|l|l|}
\hline Variable & Number & Percentage \\
\hline No school feeding to encourage students to come & 3 & 18.75 \\
\hline Unsatisfying school environment & 1 & 6.25 \\
\hline Closed and muddy roads during rainy season & 2 & 12.50 \\
\hline Students go to practice farming in the rainy season & 1 & 6.25 \\
\hline No water source in the school & 1 & 6.25 \\
\hline Irregular coming to school and dropout & 2 & 12.50 \\
\hline Weak desire for education from the families & 2 & 12.50 \\
\hline Unsufficient number of teachers & 1 & 6.25 \\
\hline $\begin{array}{l}\text { Low economic situation of the family (they want their children to } \\
\text { help them by working) }\end{array}$ & 1 & 6.25 \\
\hline $\begin{array}{l}\text { Inability of teachers to come to school in the rainy season (almost all } \\
\text { teachers do not live permanently in the community/village }\end{array}$ & 1 & 6.25 \\
\hline Unsufficient seating & 1 & 6.25 \\
\hline
\end{tabular}

Table 12 above shows that the variables that threaten the education of male students included school feeding, closed and muddy roads during the rainy season and the weak desire for education from the families.

Table 13 below provides data for threats to the education of female students. 
Table 13. Threats to the education of female students

\begin{tabular}{|l|l|l|}
\hline Variable & Number & Percentage \\
\hline $\begin{array}{l}\text { No school feeding to encourage students to come (e.g. World Food } \\
\text { Programme stopped school feeding) }\end{array}$ & 1 & 9.09 \\
\hline Closed and muddy roads during rainy season & 2 & 18.18 \\
\hline $\begin{array}{l}\text { Some families go back to their home land to practice farming in the } \\
\text { rainy season (semi-nomads) }\end{array}$ & 1 & 9.09 \\
\hline Traditions and customs (encourages early marriage for girls) & 2 & 18.18 \\
\hline Weak desire from the families for girls' education & 3 & 27.28 \\
\hline Separated parents and family clashes and disagreements & 1 & 9.09 \\
\hline Girls work at home to help the mother & 1 & 9.09 \\
\hline
\end{tabular}

Table 13 above shows that the threats to the education of girls included the weak desire from the families, tradition and customs that encouraged early marriages and closed and muddy roads during the rainy season.

Question 6: What are the average numbers of school days for the school year and how much of the curriculum are teachers able to cover during a school year with little or no conflicts compared to school year with a lot of conflicts and natural disasters?

Principals indicated that the average number of school days for a school year was 235 days while Table 14 below shows how much work teachers are able to cover in a school year with little or no conflicts compared to a school year with a lot of conflicts and natural disasters.

Table 14. Percentage of Curriculum covered during the year

\begin{tabular}{|l|l|}
\hline Year & Percentage of Curriculum covered \\
\hline With little or no conflicts & 91 \\
\hline $\begin{array}{l}\text { With conflicts and natural } \\
\text { disasters }\end{array}$ & 79 \\
\hline
\end{tabular}

Table 14 shows that for an ideal year with very little conflicts and disruptions, about 91 percent of the curriculum is covered while only 79 percent of the curriculum is covered due to conflicts and natural disasters.

\section{Discussion}

This section will be centered on three broad areas- teacher quality, textbooks, and threats to the education of the learner.

\section{Teacher Quality}

Table 7 showed that more than 25 percent of teachers had secondary school certificates and about 13 percent had no teaching certificate. There is therefore the need to upgrade the 
teaching abilities/ skills of these teachers so that they can provide more quality instruction to learners. Hammond (2000a) in reviewing research showed that more effective teachers generally possess the following qualities:

- Knowledge of how to teach others in that area (content pedagogy), in particular how to develop higher-order thinking skills

- An understanding of learners and their learning and development - including how to assess and scaffold learning, how to support students who have learning differences or difficulties, and how to support the learning of language and content for those who are not already proficient in the language of instruction

- Adaptive expertise that allows them to make judgments about what is likely to work in a given context in response to students' needs.

In another study, Hammond (2000b), pointed out that the "effects of well- prepared teachers on student achievement can be stronger than the influences of student background factors such as poverty and language" p 33. In the same manner, Evertson, Hawley and Zlotnik (1985) and Monk (1994) and Ashton and Crocker (1987) have found positive effects of teachers' formal educational training on student learning. In essence, teachers who had formal teacher education training had positive effects on student learning and achievement compared with teachers with no teaching certificates.

\section{Textbooks}

The study found that there were insufficient textbooks for all three subject areas of English Language Arts, Mathematics and Science. In many developing societies, teachers depend on the textbook for instruction. Content area textbooks, curriculum materials, computer technology, supplementary resources are very important for the education of the learner and the consequences of not having them are harsh and detrimental to student progress (OECD, 2009 p.33). In a review of research, Fuller and Heyneman (1989) found that there was a positive effect of the prevalence of textbooks and instructional materials/resources on student academic achievement.

Apart from the insufficiency of these textbooks, principals indicated they were not written at the learner. This invariably means the texts will fall either at students' instructional level or frustration level. Teachers need to be trained on how to make these texts more readable to learners and secondly, textbook writers should be sensitive to this issue in the future.

Threats to the education of the learner

Three issues were the major threats to the continued education of the learner-(1). Feeding during school hours (2) lack of family support (3) early marriages for the girls. In terms of family support, Government and Non-Governmental Organizations' operating in the area need to run campaigns that encourage parents to send their children to school. Such campaigns should include the potential earning capacity of those who have gone to school versus those who have not and other incidental benefits associated with schooling. As for girls and education, one of the goals of Education for All is gender equality in basic 
education by 2015. Campaigns should be held to encourage parents to not allow early marriages. In some countries, laws have been passed forbidding marriages for girls under the age of 16. This should be encouraged in this area of Sudan to allow more girls to complete basic education.

\section{Looking Ahead}

This was an exploratory study and there will be a need to replicate this type of study for other areas of conflict in Sudan and other countries of the region. Moreover, there is the need to do a biannual survey of the conditions of education in these areas riddled with conflict to enable proper statistics and adequate planning. Principals indicated that the textbooks were not suitable. There may be the need to analyze the textbooks in terms of readability, cultural content, and gender role content further to see how the textbooks used could be made more relevant and suitable to learners. There will be the need to study teachers' teaching strategies in light of the unavailability and the unsuitability of textbooks. Finally, there will be also the need in the future to compare student performance in national examinations from these war torn communities with students in parts of Sudan that have not been afflicted by war.

\section{Conclusion}

This exploratory study investigated the status of education in war torn communities of Eastern Sudan. An analysis of data from seven principals for all the schools in the area showed four of the schools were built by non -governmental organization's while three were built by the Government; that more than 57 percent of teachers had a bachelor's degree with a teaching certificate, that the average teaching experience for male teachers was 15 plus years and for female teachers, it was a little more than 6 years. In the areas of English Language, Mathematics and Science, it was found that textbooks were not available for about 50 percent of the students and that these textbooks were not at the level of the student. There were several threats to the continued education of the learner, the three most important being lack of feeding during the school day for students, lack of family support and early marriages for the girls. Recommendations in the study included campaigns to encourage students to stay in school, and the possibility of some law that will discourage parents from allowing early marriages (for ages less than 16) for the girls. Finally there was a need to continually upgrade the teaching abilities of teachers without teaching qualifications since research has shown that a well-qualified teacher, with a teaching certificate will do more for the educational attainment of the learner.

\section{References}

Ashton, P., \& Crocker, L (1987) Systematic study of planned variations: The essential focus of teacher education reform. Journal of Education Research, 2-8.

CIA World Factbook. (2014). Sudan. https:/www.cia.gov/library/publications/the-world-factbook/geos/su.html Retrieved online July 2014 
Darling-Hammond, L. (2000a). Policy Brief: Recognizing and Developing effective teaching: What Policy should Know and Do. http://www.nea.org/assets/docs/HE/Effective_Teaching_-_Linda_Darling-Hammond.pdf

Retrieved October 24, 2013.

Darling- Hammond, L. (2000b). Teacher Quality and Student Performance: A Review of State Policy Evidence. Education Policy Analysis Archives, 8(1),1-44.

Department for International Development. (2012). DFID Sudan-Operational Plan 2011-2015. Department for International Development. https:/www.gov.uk/government/uploads/system/uploads/attachment_data/file/67374/sudan-2 011.pdf. Retrieved July 28, 2014

Evertson, C., Hawley, W, \& Zlotnik, M. (1985). Making a difference in educational quality through teacher education. Journal of Teacher Education, 36(3), 2-12. http://dx.doi.org/10.1177/002248718503600302

Fuller, B., \& Heyneman, S. (1989) Third World School Quality: Current Collapse, Future Potential. Educational Researcher, 18(2), 12-19

Monk, D.H. (1994). Subject matter preparation of secondary math and science teachers and student achievement. Economics of Education Review, 13(2), 125-145. http://dx.doi.org/10.1016/0272-7757(94)90003-5

Norwegian Agency for Development Cooperation. (2011). Gender Review: Report Royal Norwegian Embassy Sudan. Norad report 17/2011 Discussion. Oslo, Norway: Norwegian Agency for Development Cooperation.

NORAD/ADRA. (2014). Working Paper on "Supporting Equity, Access and Quality in Education" personal communication with Dr. R. Gindeel, Afhad University, Khartoum, Sudan.

OECD. (2009). Creating effective teaching and Learning Environments: First result from TALIS. http://www.oecd.org/education/school/43023606.pdf Retrieved June 01, 2014.

UNESCO.(nd). World Declaration of Education for All http://www.unesco.org/education/efa/ed_for_all/background/jomtien_declaration.shtml Retrieved June 12, 2007

UNESCO. (2012). From Access to Equality: Empowering Girls and Women Through Literacy and Secondary Education. Paris, France: UNESCO.

USAID (2008).Education from a Gender Equality Perspective. Washington, D.C.: USAID's Office of Women in Development. GEW-I-00-02-00021-00, Task Order \#1, EQUATE: Achieving Equality in Education

UNICEF. (nd) UNICEF Data Monitoring the Situation of Women and Children. http://data.unicef.org/education/overview Retrieved October 10, 2014. 